\title{
Estudio de dosificaciones en laboratorio para pavimentos porosos de hormigón
}

\section{Laboratory study of mixture proportioning for pervious concrete pavement}

\author{
Javier Castro*1, Hernán de Solminihac**, Carlos Videla**, Bonifacio Fernández** \\ * Purdue University, ESTADOS UNIDOS \\ ** Pontificia Universidad Católica de Chile, CHILE
}

\begin{abstract}
Fecha de recepción: 16/ 09/ 2009 Fecha de aceptación: 15/ 10/2009 PAG. $271-284$

Resumen

El trabajo presentado en este estudio muestra la deducción de una ecuación que permite dosificar hormigones porosos en función de la razón agua-cemento y del porcentaje de vacíos interconectados que se requieren en el hormigón endurecido. Usando esta ecuación se analizó el comportamiento de 18 mezclas de hormigón poroso conteniendo razones agua-cemento entre 0,29 y 0,41. Las probetas fueron fabricadas en laboratorio y compactadas con rodillo pesado simulando el proceso constructivo en terreno. Los resultados permiten caracterizas de buena forma el comportamiento estructural e hidráulico de estas mezclas. Relaciones entre el porcentaje de vacíos en el hormigón endurecido y la tasa de infiltración, la resistencia a flexotracción y la densidad en estado fresco son presentadas.
\end{abstract}

Palabras Clave: Hormigón poroso, pavimentos porosos, permeable, drenante, infiltración

Abstract

The present research shows the results of an equation that allows to dose pervious concrete in function of water to cement ratio and the required interconnected void content in hardened concrete. Eighteen different mixtures - with w/c ratio between 0.29 and 0.41 - were analyzed using this equation. The samples were made in the laboratory and compacted with a heavy roller simulating site conditions. The results allow a good characterization of these mixtures both mechanical and hydraulic behavior. Relationships between void contents, infiltration rate and flexural strength were found.

Keywords: Porous concrete, pervious pavement, infiltration

\section{Introducción}

El extenso uso de pavimentos impermeables trae consigo, sobre todo en áreas de un importante desarrollo urbano, considerables problemas en la evacuación de las aguas lluvias y en las condiciones de escurrimiento aguas abajo. El uso indiscriminado de estas estructuras en áreas urbanas, disminuye notoriamente la capacidad de recarga natural de agua en los terrenos, e incrementa de forma considerable el volumen y el caudal del escurrimiento superficial, aumentando el riesgo de provocar inundaciones en los sectores más bajos de las urbanizaciones (Castro, 2004). Además, cuando el agua de las Iluvias escurre, arrastra consigo materiales sólidos y varios contaminantes depositados en calles y estacionamientos, contaminándola (Smith, 2001).

\section{Introduction}

The large use of impermeable pavement, over all in areas of significant urban development, has brought big problems to evacuate rain water, which drains down to lower areas. The indiscriminate use of these structures in urban areas diminishes notoriously the land natural water load capacity increasing; volume and superficial draining flow, as well as flood risks in down urbanized areas (Castro, 2004). Besides when rain water drains, is polluted for collecting all the solid materials that were on the streets and parking places (Smith, 2001).

\footnotetext{
1 Autor de correspondencia / Corresponding author

E-mail: jcastro@purdue.edu
} 
Para disminuir los efectos relacionados a las dos situaciones mencionadas, en los últimos años se ha desarrollado a nivel mundial un modo alternativo de diseñar pavimentos, construyendo estructuras que permitan el paso del agua a través de la capa superficial hacia el interior de la estructura (EPA, 1999), evitando así la acumulación de agua en su superficie y el escurrimiento superficial aguas abajo, condiciones que generan los dos problemas asociados a pavimentos impermeables. Dependiendo del objetivo específico, el agua infiltrada hacia el interior de la estructura podrá ser tratada de modos diferentes, para lo cual es necesario un diseño especial de todo el pavimento.

En el caso de los pavimentos de carreteras o vías muy transitadas, la configuración de la estructura de diseñará considerando un pavimento tradicional, al que se le adicionará en su parte superior una capa permeable. El agua infiltrada llegará hasta la capa impermeable y será conducida lateralmente fuera de la estructura. Con esto se logra evacuar rápidamente el agua superficial disminuyendo el riesgo en los eventos de lluvias. En el caso de los pavimento urbanos de baja solicitación, la configuración de la estructura podrá incluir capas permeables bajo la carpeta de rodado (base y/o sub-base) de modo de actuar como estanque de almacenamiento, y si las condiciones lo permiten, de estanque de infiltración. En forma general, las estructuras de pavimentos capaces de infiltrar el agua a través de su capa superficial reciben comúnmente el nombre en inglés de "pervious pavement", esta definición agrupa en forma más amplia dos tipos de estructuras: los pavimentos permeables y los pavimentos porosos.

Los pavimentos permeables son estructuras construidas con materiales impermeables, generalmente prefabricados, en las que su diseño geométrico permite infiltrar el agua superficial hacia las capas inferiores, ya sea a través de orificios en los bloques o de espacios entre las juntas.

Los pavimentos porosos en cambio, son estructuras de hormigón o asfalto, fabricados con granulometrías sin finos, y que son en sí mismas permeables, escurriendo el agua a través de vacíos interconectados que generalmente alcanzan un valor entre 15 y 25\% (Meininger, 1988; Debo \& Reese, 1995; Ghafoori \& Dutta, 1995). Al ser estructuras construidas con materiales distintos a los utilizados comúnmente en pavimentos, el diseño de las mezclas de estos pavimentos requiere de un estudio más acabado. Es esta configuración, con capas inferiores permeables, la que se considera en esta investigación.
During last years, and in order to diminish the effects related to these two situations already mentioned, there have been worldwide alternative developments of pavements, building structures that allow water to move down from the superficial layer towards the inner of the structure. (EPA, 1999); avoiding thus, the accumulation of water on the surface and its drainage to down areas; problems associated to impermeable pavements. Depending on the specific objective, the water that is infiltrated into the inner structure shall be treated in different ways, for that reason a special design of the entire pavement will be needed.

In the case of highways or high traffic roads, the configuration of the structure will be designed considering traditional pavements with a permeable layer on its top. The infiltrated water will reach the impermeable layer and then it will be conducted outside from one side of the structure. With that, the superficial water is quickly evacuated diminishing the risk of rain events. In the case of low traffic roads, the structure shall consider permeable base and/or sub-base in such a way to act as storage tank, and if conditions allow it, as permeation tank. In general terms the pavement structures that are able to infiltrate water from its superficial layer receive in English the name of "pervious pavement", this definition groups in a wider way two kinds of structures: permeable and porous pavements.

Permeable pavements are structures built with impermeable materials, usually pre-manufactured, which geometrical design that allows to infiltrate the superficial water to lower layers, due to the brick voids or the spaces between joints.

Porous pavement, by its side, are concrete or asphalted structures, manufactured with grading without fines, which are intrinsically permeable, draining the water through interconnected voids that usually reach values between 15 y 25\% (Meininger, 1988; Debo \& Reese, 1995; Ghafoori \& Dutta, 1995). The design of these pavement mixtures requires a detailed research, because these structures are built with different materials than those typically used. Is in this configuration with down and permeable layers where this research is focused. 
El trabajo que aquí se presente ha sido parcialmente publicado previamente en De Solminihac et al (2007). En el actual trabajo se presenta en detalle la deducción de las ecuaciones para dosificar hormigones porosos, que es la base para todo el trabajo de laboratorio expuesto. Se incluyen resultados de relaciones entre el porcentaje interconectado de vacíos en el hormigón endurecido con la resistencia a flexotracción a 28 días y la tasa de infiltración, que permitirían dosificar hormigones permeables en función de la resistencia o infiltración requeridos. Además se presentan relaciones entre el porcentaje de vacíos, la densidad del hormigón fresco y el tiempo de infiltración medido con un permeámetro de carga variable, que pueden ser usados como herramientas para el control de calidad de las mezclas puestas en terreno.

\section{Sistema de dosificación}

Si bien existe información del uso de hormigones para este tipo de pavimentos desde hace más de veinte años, incluyendo dosificaciones y recomendaciones constructivas, no existen hasta ahora investigaciones que utilicen un sistema de compactación similar al usado en terreno para caracterizar el comportamiento del material. Los autores creen que los resultados de este trabajo permitirán caracterizar de mejor forma el comportamiento de este hormigón en estado fresco, lograr mayor certeza sobre el comportamiento mecánico e hidráulico en estado endurecido, y optimizar el uso del cemento para lograr las mayores resistencias a flexotracción para cada razón agua-cemento $(w / c)$.

El sistema de dosificación desarrollado en esta investigación, y cuya deducción es presentada a continuación, se basa en la cantidad de vacíos disponibles originalmente en el árido y que es reducido al agregar la pasta de cemento.

En teoría si se utiliza un árido con elevado porcentaje de huecos (por ejemplo $40 \%$ ), y se agrega un volumen de pasta de cemento igual al $25 \%$ del volumen total, la pasta llenara solo parcialmente los vacíos disponibles quedando un volumen de vacíos de 15\%. Para un volumen unitario de árido, la densidad de la mezcla puede obtenerse sumando la masa de los componentes y dividiéndola por el volumen unitario, obteniéndose lo que Ilamaremos densidad teórica, mostrada en la Ecuación (1).
De Solminihac et al. (2007) partially published the results of this study. This paper explains how the dosage equations for pervious concrete were obtained, which is the basis of the entire laboratory research exposed. Included is the result of the relation between the void interconnected content in hardened concrete with flexural strength that appears in 28 days time and permeation rate, which will allow to dose permeable concrete in function to its strength or required permeation. Besides there are relations between void percentages, fresh concrete unit weight and the permeation time measured with a Falling Head Permeameter, which can be used as tool to control quality of the field mixtures.

\section{Mixture design system}

Even when there is information about the use of this kind of concrete, for more than twenty years, dosage and construction recommendations included, so far there has not been a research using similar compacting system as the one used on site to characterize the material behavior. The authors believe that the results of this research will allow a better way of characterizing this concrete behavior in fresh state, reaching more accuracy about the mechanical and hydraulic behavior in hardened state, and optimizing the use of cement to reach higher flexural strength to each water- cement ratio (w/c).

This research dosing system is based on the void content originally available in the aggregate and that it is reduced when adding cement paste.

In theory using aggregate with high percentage of voids (example 40\%), and a volume past that represents the $25 \%$ of the total volume is added, the paste will only fill partially the aggregate voids, remaining a 15\% empty. For a unitary aggregate volume, the mixture unit weight may be obtained adding the components mass and dividing it by the unitary volume, which is called "theoretical unit weight" shown in Equation (1). 
Donde A es la masa del árido, C es la masa del cemento, y $W$ es la masa del agua.

Sin embargo, en la práctica, una vez que la los materiales son mezclados y el hormigón es compactado, la pasta no sólo Ilenará los huecos entre los árido sino que también se introducirá entre las partículas de agregado, separándolas e incrementando el volumen original del árido, por lo que el volumen final será mayor por efecto de este "esponjamiento" de la mezcla. Esta situación es mostrada esquemáticamente en la Figura 1. De acuerdo a este esquema, la densidad real y el porcentaje de vacíos en la mezcla pueden ser calculados usando las Ecuaciones (2) y (3) respectivamente.
Where $A$ is the mass aggregate, $C$ is the cement mass, $y$ $W$ is water mass.

Nevertheless, in practice, once that materials are mixed and concrete compacted, the paste will not only fill the voids among aggregates but it will also get into the aggregate particles, separating and increasing the aggregate original volume, because of that the final volume will be higher due to "bulking effect" on the mixture. The bulking effect is shown step by step on Figure 1. According to this Figure, the actual unit weight and the percentage of voids in the mixture may be calculated using Equations (2) and (3) respectively.

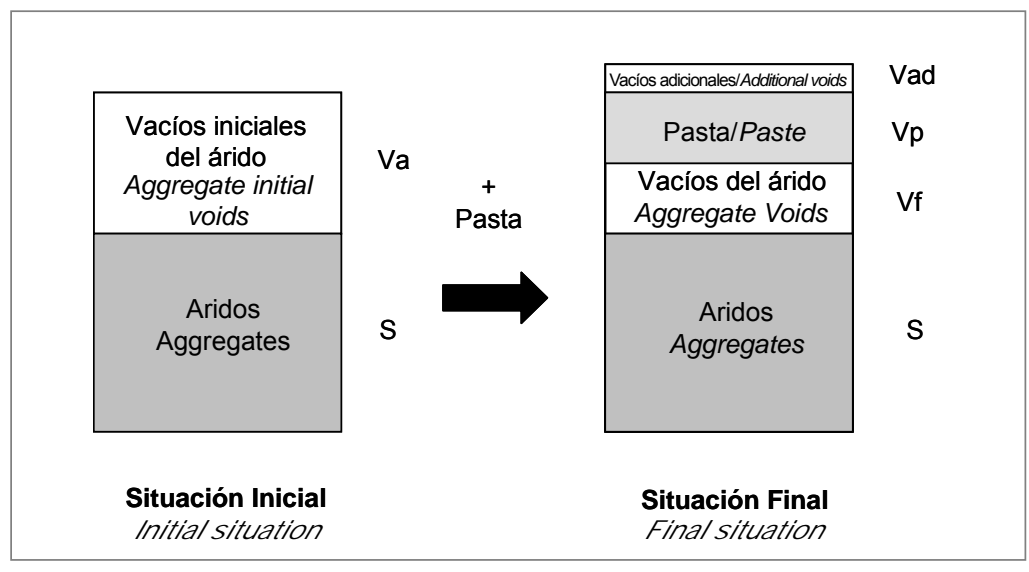

Figura 1. Efecto de la inclusión de pasta de cemento en el árido con alto contenido inicial de vacíos

Figure 1. Effect of including cement paste in the aggregate with high content of initial voids

$$
\text { Densidad Actual / Unit Weight }(\text { Dr }) \quad=\left(\frac{A+C+W}{1+V a d}\right) \text { (2) }
$$

Porcentaje de vacíos en la mezcla/Void content $(V m)=\left(\frac{V a-V p+V a d}{1+V a d}\right)$ (3)

Donde Va es el volumen inicial de vacíos en el agregado, Vp es el volumen de pasta adicionado, y Vad es el volumen de vacíos adicionales generados por la separación de los agregados. El aumento de volumen (Vad) puede expresarse a través de la proporción entre la densidad real y la densidad teórica, relación que en esta investigación se define en la Ecuación (4) como Factor de Compactación (FC).
Where Va is the initial volume of aggregate voids, $\mathrm{Vp}$ is the added paste volume, and Vad is the volume of additional voids produced by the same aggregate separation. The volume increase ( $\mathrm{Vad}$ ) may be expressed through the proportion between actual and theoretical unit weight, ratio that in this investigation is defined in Equation (4) as Compaction Factor (CF)

Factor de compactación (FC)/Compaction Factor $(C F)=\left(\frac{\text { Actual Unit Weight }}{\text { Theoretical Unit Weight }}\right)$ (4) 
Reemplazando las Ecuaciones (1) y (2) en la Ecuación (4) y luego despejando para la variable "Vacíos adicionales (Vad)" se tiene que:
Replacing Equations (1) y (2) in Equation (4) and then solving it for variable "additional voids" Vad Equation 5 is obtained:

$$
\operatorname{Vad}=\left(\frac{1-F C}{F C}\right)
$$

Si además se reemplaza la Ecuación (5) en la Ecuación (3) se obtiene la Ecuación (6):
If equation (5) is replaced in Equation (3), Equation (6) is obtained:

Porcentaje de vacíos en la mezcla Mixture/void content $(V m)=(V a-V p) \cdot F C+(1-F C)$ (6)

La Ecuación 6 asume que todos los vacíos estarán conectados en el hormigón endurecido. En la práctica, se debe considerar que en la mezcla de hormigón se generaran algunos vacíos no conectados, de modo que el porcentaje interconectados de vacíos del hormigón endurecido será menor al calculado a través de la Ecuación (6). Investigaciones previas (FCPA, 1993), han medido una relación entre el porcentaje teórico calculado en forma gravimétrica $(\mathrm{Vm})$ y el porcentaje medido de vacíos conectados (Vcon), la que es expresada en la Ecuación (7).
Equation 6 assumes that in hardened concrete all the voids will be connected. In practice, it should be considered that in concrete mixture there are some unconnected voids, thus the interconnected percentage of hardened concrete voids will be less than the one calculated through Equation (6). A previous research (FCPA, 1993) measured the relation between the theoretical calculated void content by a grading procedure $(\mathrm{Vm})$ and the connected void content (Vcon), which is expressed in the Equation (7).

Porcentaje conectado de vacíos/Connected Void Content $($ Vcon $)=0.898 \cdot V m-3.1$ (7)

Asumiendo además que el volumen de pasta de cemento se puede calcular como la suma del volumen original de cemento, agua y aditivos, se tendrá que el volumen de pasta para un metro cúbico de hormigón puede ser expresado a través de la Ecuación (8):
Assuming that the cement paste volume may be calculated as the addition of the cement original volume, water, and additives, then paste volume for one cubic meter of concrete may be expressed through the following Equation (8):

$$
V p=M c\left(\frac{1}{\gamma_{c}}+(w / c)+\frac{D_{a d}}{\gamma_{a d}}\right) \text { (8) }
$$

Donde Mc es la masa de cemento $(\mathrm{kg}), \gamma_{c}$ es el peso especifico del cemento, Dad es la dosis de aditivo (\% masa de cemento) y $\gamma$ ad es el peso especifico del aditivo. Reemplazando las Ecuaciones (7) y (8) en la Ecuación (6) se puede deducir la Ecuación (9), que permite calcular la dosis de cemento para un hormigón poroso en función de la cantidad de vacíos conectados en el mezcla endurecida, dada la razón agua-cemento.
Where Mc is the cement mass $(\mathrm{kg}), \gamma_{C}$ is the cement specific weight, Dad is the additive proportion (\% cement mass) and ?ad is the additive specific weight. Replacing Equations (7) and (8) in Equation (6) takes to Equation (9), which allows to calculate the cement dose for a pervious concrete as a function of the void quantity connected in the hardened mixture, given the watercement ratio. 


$$
M c(k g)=\left[\frac{(10 V a-1000) F C+965.48-11.14 V c o n}{\left(\frac{1}{\gamma_{c}}+(w / c)+\frac{D a d}{100 \gamma_{a d}}\right) F C}\right]
$$

\section{Programa experimental}

\subsection{Materiales}

En este estudio utilizó solamente agregado grueso sin finos tamaño máximo nominal de $10 \mathrm{~mm}$ granulometría No8 según norma ASTM C33 (ASTM, 2008) con densidad de $1520 \mathrm{~kg} / \mathrm{m}^{3}$, un porcentaje de huecos de $43 \%$, y absorción del árido de $1.6 \%$. Se usó cemento portland puzolánico de alta resistencia inicial con peso especifico 2.95 y aditivo plastificante reductor de agua en dosis de $0.5 \%$ del peso del cemento con peso especifico 1.16.

\subsection{Variables experimentales y dosificaciones}

Las variables independientes consideradas fueron el porcentaje real de vacíos y la razón agua-cemento de la mezcla. Se determinó dosificar hormigones que en su estado endurecido tuvieran $15 \%$, $17 \%$ y $19 \%$ de vacíos, en orden a analizar el efecto de esta variable sobre la resistencia y permeabilidad de las mezclas. La variable w/c se fijó en $0.29 ; 0.32 ; 0.35 ; 0.38 ; 0.41$ y 0,44. Estos valores fueron escogidos para analizar el efecto de la consistencia de la pasta de cemento sobre las propiedades de las mezclas. De este modo 18 dosificaciones diferentes fueron consideradas en este trabajo de laboratorio.

El valor de FC era desconocido al momento de realizar las dosificaciones. Por esta razón se asumió que esta variable sería igual a 0.95 como una primera aproximación. Una vez que las mezclas hayan sido preparadas, los valores reales de FC serán reportados para cada mezcla y el porcentaje de vacíos conectados será corregido.

La dosis de cemento se determinó para cada mezcla utilizando la Ecuación (9) deducida en la sección 2. La Tabla 1 muestra un resumen de las dosis de cemento calculadas para cada mezcla.

\section{Experimental program}

\subsection{Materials}

This research used only coarse aggregate with maximum aggregate size of $10 \mathrm{~mm}$ grading $\mathrm{N}^{\circ} 8$, according to ASTM C33 (ASTM, 2008) standard, with a unit weight of $1520 \mathrm{~kg} / \mathrm{m}^{3}$, void percentage of $43 \%$, aggregate absorption of $1.6 \%$. Puzolanic Portland Cement with high initial strength and gravity of 2,95 was used, and also a water reducer admixture at $0.5 \%$ of the cement weight with specific gravity of 1.16 .

\subsection{Dosing and Experimental Variables}

The independent variables considered were the real void percentages and the mixture water cement ratio. In order to analyze this variable effect on the permeability and strength of mixtures, concretes that in hardened state had 15,17 , and $19 \%$ of voids received dosage. The $w / C$ variable was set on $0.29,0.32,0.35,0.38,0.41$ and 0.44 . These values were chosen to analyze the effect of the cement paste consistency on the mixture properties. Thus, 18 different mixtures proportion were considered in this laboratory work.

Due that CF value was unknown at the moment of dosage, 0.95 was considered as first approximation. The actual CF values for each mixture could be reported, and the connected void content rectified once that those mixtures are fabricated.

Each cement mixture dose was determined using the Equation (9), obtained in section 2. Table 1 shows a summary of the cement dosage calculated for each mix.

Tabla1. Dosis de cemento para hormigones porosos confeccionados en esta investigación

Table 1. Cement dosage for pervious concrete manufactured in this investigation

\begin{tabular}{|c|c|c|c||}
\hline \multirow{2}{*}{} & \multicolumn{4}{|c||}{$\begin{array}{c}\text { Porcentaje real de huecos en la mezcla / } \\
\text { Real percentage of voids in the mix }\end{array}$} \\
\cline { 2 - 4 } & $15 \%$ & $17 \%$ & $19 \%$ \\
\hline \multirow{2}{*}{$w / \mathrm{c}$} & \multicolumn{3}{|c|}{ Dosis de cemento $\left(\mathrm{kg} / \mathrm{m}^{3}\right) /$ Cement dosage $\left(\mathrm{kg} / \mathrm{m}^{3}\right)$} \\
\hline 0.29 & 427 & 390 & 353 \\
\hline 0.32 & 408 & 373 & 337 \\
\hline 0.35 & 390 & 355 & 323 \\
\hline 0.38 & 374 & 342 & 309 \\
\hline 0.41 & 359 & 328 & 297 \\
\hline 0.44 & 345 & 315 & 285 \\
\hline
\end{tabular}




\subsection{Preparación de probetas}

De acuerdo con la experiencia internacional, las mezclas de hormigón poroso deben ser compactadas con un rodillo pesado de ancho mayor que el de la losa a hormigonar (FCPA, 1990; GCPA, 1997; Reyes \& Torres, 2002; Kwiatkowski, 2003). Por esta razón se diseñó un rodillo de $300 \mathrm{~mm}$ de diámetro, $600 \mathrm{~mm}$ de ancho y 115 $\mathrm{kg}$ de peso, que proporciona presiones similares a las utilizadas en terreno (0.08 MPa). Utilizando este rodillo, se confeccionaron probetas de $150 \mathrm{~mm}$ de espesor, 400 $\mathrm{mm}$ de ancho y $550 \mathrm{~mm}$ de largo, las que por su tamaño se denominaron losetas (Figura 2).

Las losetas fueron desmoldadas después de 24 h, y posteriormente cubiertas con plástico durante $7 \mathrm{~d}$. Luego, estas losetas fueron cortadas obteniendo dos probetas prismáticas de las mismas dimensiones que las usadas en los ensayos de flexotracción (150 x 150 × 550 $\mathrm{mm}$ ). Para disminuir posibles efectos de las paredes de los moldes, las probetas fueron cortadas desde la sección central, despreciando así los $50 \mathrm{~mm}$ exteriores del ancho de las losetas.

Dieciocho dosificaciones distintas fueron analizadas. Para cada una de ellas se realizaron dos mezclas o "amasadas" en días diferentes (36 mezclas en total). Dos losetas fueron confeccionadas con cada amasada, con lo que 72 losetas fueron construidas (4 losetas por cada dosificación) y 144 prismas fueron cortados en total.

\subsection{Ensayos desarrollados}

Tres diferentes ensayos fueron desarrollados: resistencia a flexotracción, determinación del porcentaje de huecos interconectados y tasa de infiltración.

Dado que estos hormigones son diseñados para ser utilizados en pavimentos, se determinó realizar el ensayo de flexotracción con carga en los tercios a los 28 días. Tres prismas por dosificación fueron testeados en flexotracción.

El porcentaje de vacíos en el hormigón fue medido usando el principio de Arquímedes del peso sumergido.

Para medir la tasa de infiltración se utilizó un permeámetro de carga variable, ensayándose las 72 losetas antes de ser cortadas (Figura 3).

\subsection{Specimen Preparation}

According to the international experience, pervious concrete mixtures should be compacted with a heavy roller, which width should be larger than that of the slab to be cast (FCPA, 1990; GCPA, 1997; Reyes \& Torres, 2002; Kwiatkowski, 2003). For this reason, a 300 $\mathrm{mm}$ diameter roller was designed, it was 600-mm wide and weighted $115 \mathrm{~kg}$ which produces similar pressures to those used on field (0.08 $\mathrm{MPa})$. This roller was used to build $150 \times 400 \times 550 \mathrm{~mm}$ specimens, which, by its size, were called small slabs (Figure 2).

The small slabs were unmold after de $24 h$, and covered with plastic sheets during 7 days. After that, these small slabs were sawed obtaining two prismatic specimens (beams), with the same size used in the flexural tests (150 × $150 \times 550 \mathrm{~mm}$ ). Specimens were sawed from its central section, in order to reduce the possible effects on the mold walls, not considering the external $50 \mathrm{~mm}$ wide strips.

Eighteen different doses were analyzed; each one receives two mixtures or batches fabricated in different days (36 batches in total). Each batch originated two small slabs, then 72 small slabs were produced (4 small slabs for each dosage) and 144 beams were sawn.

\subsection{Testing}

Three different tests were carried out: flexural strength (rupture modulus), quantifying the interconnected voids content, and permeation rate.

Because these concretes were designed to be used in pavements, it was determined to do a flexure test in 28 days, with loading at the thirds. Three dosing beams received a flexure test.

The void content in concrete was measured using Archimedes principle of immersed weight.

Before sawing a variable load permeameter was used to measure permeation on the 72 small slabs (Figure 3). 


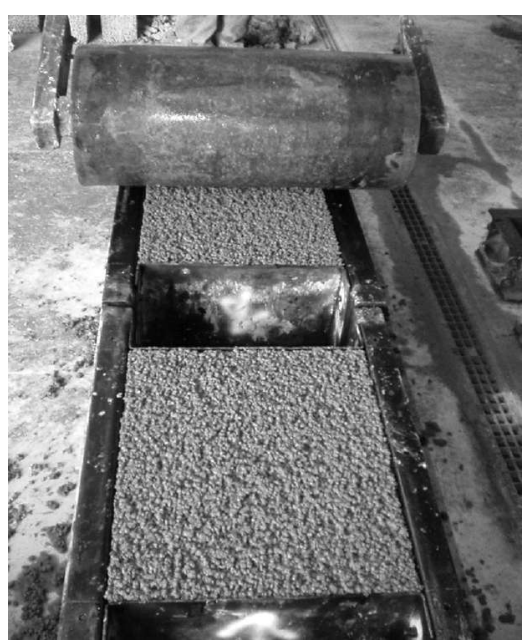

Figura 2. Compactación de las losetas en sus moldes

Figure 2. Compacting small slabs in its molds

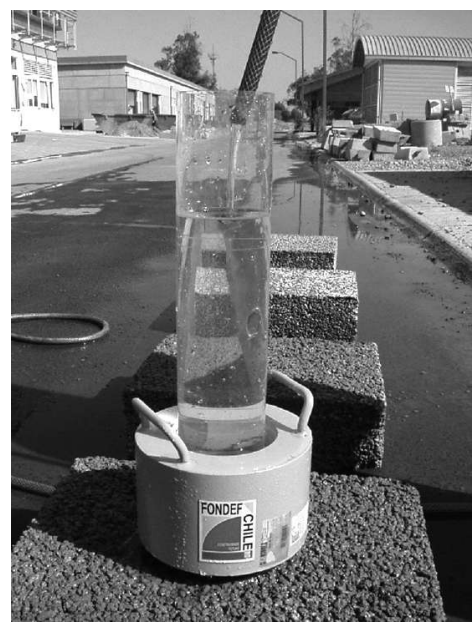

Figura 3. Ensayo con permeámetro de carga variable Figure 3. Falling Head Permeameter

\section{Presentación y análisis de resultados}

\subsection{Valores reales del Factor de Compactación}

Como se mencionó, para las dosificaciones se consideró un factor de compactación constante e igual a 0.95. Sin embargo, este factor resultó ser variable en la práctica. De acuerdo a la evidencia experimental obtenida en esta investigación, se determinó que este valor varía entre 0.84 y 0.99 , dependiendo fundamentalmente de la razón w/c para una granulometría fija. A partir de los resultados obtenidos se estableció la Ecuación (10), que relaciona el Factor de Compactación real con la razón w/c.

\section{Results and analysis presentation}

\subsection{Actual compaction factor}

As mentioned above, a constant compacting theoretical factor equal to 0.95 was considered to dose mixtures. Nevertheless, in the real experience this factor varies. According to the test evidence obtained in this research, it was determined that compaction factor value varies between 0.84 y 0.99, mainly depending on $w / C$ for a fixed aggregate size and grading. From the results, it was possible to obtain Equation (10), which relates the actual Compacting Factor with w/c. 


$$
F C=-3.37 \cdot(w / c)^{2}+3.49 \cdot(w / c)+0.11 \quad\left(\mathrm{R}^{2}=0.996\right)
$$

\subsection{Comportamiento de las mezclas con alta razón agua- cemento}

En las mezclas con $w / c 0.41$ y 0.44 se observó notorio escurrimiento de la pasta de cemento hacia la parte inferior de las probetas, generando probetas heterogéneas verticalmente. En el caso de las mezclas con $w / c 0.44$ el escurriendo formó una capa impermeable en la parte baja de la probeta. Por esta razón, dichas mezclas serán consideradas en forma especial en el análisis.

\subsection{Comparación del porcentaje calculado y el porcentaje medido de vacíos}

Una vez conocido los valores de FC para cada w/c, es posible corregir el porcentaje de vacíos utilizado en la Ecuación (9) para cada una de las mezclas. La Figura 4 muestra una comparación entre estos valores calculados y los valores de vacíos medidos en las muestras endurecidas. En esta figura la línea segmentada representa una hipotética correlación 1:1 entre los valores medidos y calculados.

\subsection{High water-cement ratio mixture behavior}

It was observed on the mix, with w/c of 0.41 and 0.44 , cement paste notoriously drained to the bottom of the specimens, producing vertical heterogeneous specimens. In the case of mixes with $w / c$ of 0.44 , the drainage formed an impermeable layer at the bottom of the specimen. For this reason these mixtures will be considered in a special analysis.

\subsection{Comparing calculated and void content}

Once FC values of each w/C are known, it is possible to rectify void contents using Equation (9). Figure 4 compares calculated values and those voids measured in hardened mixtures. In this Figure the dashed line represents a hypothetical 1:1 correlation between measured and calculated values.

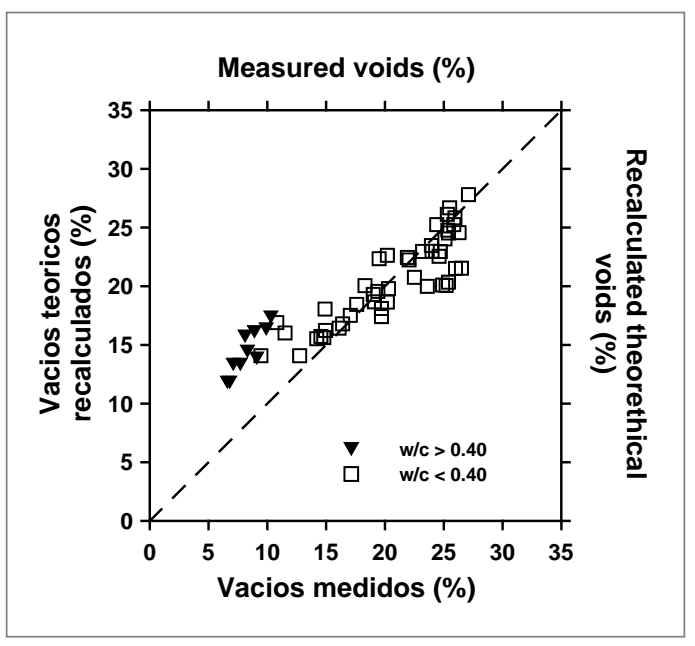

Figura 4. Comparación entre porcentaje de vacíos medidos y porcentaje de vacíos teóricos, calculados con Ecuación (9) y (10)

Figure 4. Comparison between measured void content and theoretical void content calculated with Equation (9) and (10)

En la Figura 4 se aprecia el efecto del escurrimiento de la pasta de cemento en los vacíos interconectados para las mezclas que contienen altas w/c. Dicho escurrimiento altera la distribución de vacíos en el hormigón y aumenta la cantidad de vacíos desconectados en la mezcla. Para las mezclas que contienen $\mathrm{w} / \mathrm{c}$ menores a 0.38 ,
Figure 4 shows the drainage effect of cement paste into the interconnected void mixtures that contain high w/c. This drainage affects the concrete void content distribution and increases the quantity of unconnected voids in the mixture. The results for mixtures with $w / c$ lower than 0.38 
los resultados muestran una buena correlación entre los valores predichos y los valores medidos, lo que permite utilizar las Ecuaciones (9) y (10) en futuras investigaciones, cuando se desee dosificar un hormigón poroso en función de la cantidad de vacíos en el hormigón endurecido.

\subsection{Resistencia a flexotracción}

En la Figura 5 (a) se presentan los resultados de los ensayos de resistencia a flexotracción a 28 días, como función del contenido de cemento para $w / c$ constantes. Basándose en estos resultados no resulta recomendable utilizar mezclas con $w / c$ menor que 0.32 en pavimentos vehiculares, pues si bien pueden resultar con mayor cantidad de vacíos, presentan bajas resistencias en comparación con las que utilizan $w / c$ mayores o iguales que 0.35. Además, estas dosificaciones mostraron desprendimiento del árido superficial por la escasa cantidad de pasta que puede retenerlos, y dificultad en la colocación debido a la baja dosis de agua.

De las curvas con razón $w / c$ desde 0.29 hasta 0.38 , a primera vista pareciera que la resistencia no sigue un patrón lógico. Para cada una de las curvas con razón w/c constante, cuando se incrementa el contenido de cemento se obtiene una dosis que maximiza la resistencia, pero al agregar más cemento la resistencia disminuye. Adicionalmente, la resistencia máxima es mayor a medida que aumenta la razón $w / c$ (comportamiento que se opone al concepto general aplicado a hormigones, donde mayores razones $w / c$ se asocian a menores resistencias), y este aumento de la resistencia está asociado a una disminución de la cantidad de cemento.

Para analizar esta situación consideraremos en primera instancia el comportamiento de las resistencias a flexotracción de mezclas con igual dosis de cemento. Debe recordarse que las razones $w / c$ consideradas en esta investigación son bastante bajas, y que si bien mayores dosis de agua puede producir una microestructura más porosa y por lo tanto menos resistente, en este caso un aumento en la cantidad de agua puede mejorar significativamente el grado de hidratación del cemento. También debe considerarse que en hormigones tradicionales la porosidad total es muy inferior comparada con los hormigones porosos, por lo tanto el efecto de reducción de porosidad (al disminuir la razón $w / c$ ) es significativo en su resistencia. En hormigones porosos, en cambio, la porosidad es elevada y el efecto de la razón $w / c$ en la porosidad total puede hacerse muy bajo comparado con el beneficio de una mayor hidratación del cemento. show a good relation between the calculated and measured values; this allows using Equation (9) and (10) for future investigations if pervious concrete dosage is going to be based on the quantity of voids present in hardened concrete.

\subsection{Flexural strength}

The Figure 5 (a) shows the results of flexural strength at 28 days, and the function of cement content at constant w/c. Based on results, it is not advisable to use mixtures with w/c lower than 0.32 in pavements, because although it has a high void content, presents low strength in comparison with those with w/c equal o higher than 0.35. Moreover, these dosages showed superficial aggregate loss produced by insufficient cement paste to hold it and weak settlement due to a low dose of water.

At first sight curves w/c from 0.29 to 0.38 in Figure 5, suggest that strength does not present a logical pattern. The increase of cement dosage at each curve with a constant w/c maximizes strength, but adding more cement decreases it. Additionally, the maximum strength is higher as the w/c increases (behavior that differs with the general concept used in concrete, where the higher $w / c$ is associated with lower strength) and this increase in strength is associated with a decrease in the quantity of cement.

To analyze this situation, the behavior of the mixture flexural strength with the same dosage of cement needs to be considered. Note that the w/c considered in this research are rather low, and that if higher water dosage may produce a more porous paste microstructure with less strength, in this case, the increase in water may significantly improve the cement hydration level. Also, it should be considered that in traditional concretes the total porosity is very small compared with pervious concrete, and then the effect of reducing porosity (diminishing the $w / c$ rate) is considerable on strength. In pervious concrete, the porosity is high and the w/c effect in porosity might be small compared with the benefit higher cement hydration. 
Para explicar ahora la forma de cada curva de $w / c$ constante se debe recordar que se está trabajando con granulometrías con un contenido elevado de vacíos y que el volumen de pasta alcanza para llenar sólo cerca de la mitad de todos los vacíos disponibles. Si bien en una probeta de hormigón tradicional el confinamiento lo entrega la pasta de cemento, que actúa como el medio en el cual las partículas se encuentran inmersas, el hormigón poroso está constituido por un verdadero esqueleto granular grueso en el que cada árido está apenas rodeado de pasta de cemento, razón por la cual la forma de los meniscos de pasta entre áridos (Fernandez Luco et al., 2000), y la trabazón o transmisión de esfuerzos por contacto del árido, son muy importantes en la resistencia de estas mezclas.

Bajo esta consideración, si desde una condición de baja dosis de cemento (extremo izquierdo de las curvas de la Figura 5 (a)), se aumenta la cantidad de pasta sin alterar su calidad (razón $w / c$ constante), la mezcla debería comenzar a resistir más. Sin embargo, si se sigue aumentando la cantidad de pasta, Ilegará un momento en que se separará tanto las partículas, que se producirá una disminución en la resistencia de los meniscos y en la trabazón de la estructura con la consecuente pérdida de resistencia de la probeta. El efecto combinado de ambas situaciones explicaría la disminución de las resistencias, justificándose de este modo la existencia de un volumen de pasta que maximiza la resistencia.

En la Figura 5 (b) se presentan los resultados de los ensayos de resistencia a flexotracción a 28 días, como función del contenido de pasta de cemento para razones w/c constantes menores o iguales a 0,38. Se puede observar que la resistencia del hormigón poroso es maximizada cuando la pasta ocupa el $25 \%$ del volumen total $(0.25$ $\mathrm{m}^{3 /} \mathrm{m}^{3}$ de hormigón). De este modo se ratifica la hipótesis planteada, "la dosis óptima de cemento está determinada por el volumen de pasta adicionado a la mezcla".

En la Figura 5 (b) también puede apreciarse el efecto del aumento de la razón w/c mencionado anteriormente. A mayor razón w/c mayor es la resistencia. Un factor adicional que ayuda a entender este comportamiento es el aumento en la fluidez de la pasta de cemento al aumentar la cantidad de agua. Debe recordarse que la cantidad total de pasta de cemento solo alcanza para recubrir los áridos dejando una cantidad considerable de vacíos entre las partículas. Un aumento en la trabajabilidad de la pasta de cemento permitiría cubrir de un modo mas efectivo los áridos, generando más y mejores puntos de contactos (meniscos), lo que repercutiría en una mayor resistencia de la estructura.
The shape of curves, at constant $w / c$ relating cement content and strength, analysis should considers the fact that is strongly affected by a high amount of mixture voids and that paste volume casts only the half. In a traditional concrete specimen, the cement paste provides confinement to aggregates and acts as the media where aggregate particles are immersed; in pervious concrete, aggregate works as a skeleton, which is almost surrounded by cement paste, that justifies why the meniscus formed between aggregates (Fernandez Luco et al., 2000), and the interlock, or transmission, are very important for mixture strength.

Under this consideration, from a low dosage perspective (curves left side Figure 5(a)); if paste content is increased without changing its quality (constant $w / c$ rate) the mixture should become stronger. Nevertheless, if the quantity of paste continues increasing, there will be a point where aggregate particles start to separate producing a decrease in the meniscus strength and interlock, with the consequently strength specimen loss. The combined effect of both situations would explain the decrease of strength, thus justifying the existence of a paste volume that maximizes strength.

Figure 5(b) shows the 28-day flexure strength tests as a function of the cement paste content for different $w / c$ up to 0.38. Results suggest that flexure strength is maximized when paste content volume is about $25 \%$ (0.25 $\mathrm{m}$ per $\mathrm{m}^{3}$ of concrete). This supports the hypothesis that the "optimum cement dose is determined by the volume of cement paste".

Figure 5(b) also shows the effect of the w/c increased previously mentioned, a higher $w / c$ means more strength. The increase of cement paste fluidity as water augments is an additional element that explains this behavior. It must be considered that the total cement paste is able to only cover aggregates leaving voids among particles. A higher workability paste would cover aggregate particles more effectively allowing them to produce more and better contact points (meniscus), which would develop higher strength. 
Si bien los resultados han sido deducidos utilizando sólo un tipo de granulometría, éstos podrían extenderse a otras granulometrías en las que la trabazón siga siendo el factor preponderante.
Even though these conclusions have been drawn using only one kind of aggregate grading curve, these could be extended to other cases where interlock is the predominant factor.

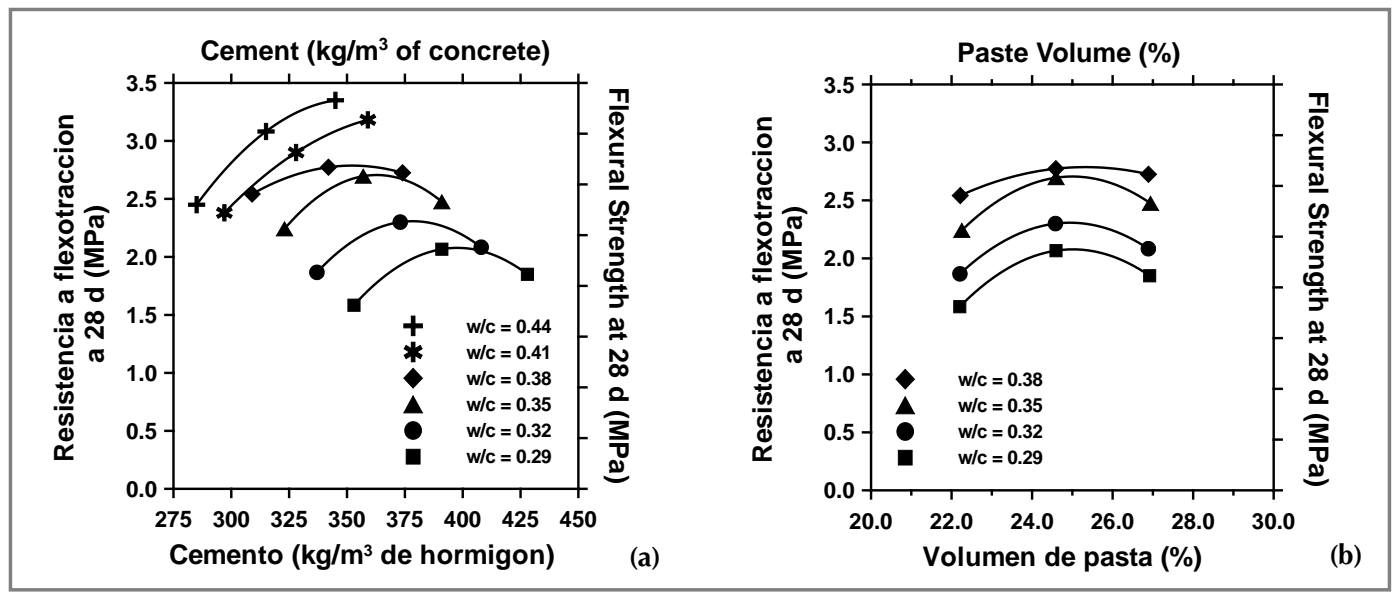

Figura 5. Efecto de la cantidad de cemento pasta en la resistencia a flexotracción a 28 días

Figure 5. Effect of the cement quantity on the flexural strength at 28 days.

\subsection{Efecto del porcentaje de vacíos en la resistencia a la flexotracción y la infiltración}

En la Figura 6 (a) se muestra una relación entre la resistencia a flexotracción a 28 días y el porcentaje real de huecos medidos para todas las probetas. En la Figura 6 (b) se muestra una relación entre tasa de infiltración medida a la edad de 28 días y el porcentaje real de huecos.

Si bien la Figura 6 muestra los resultados obtenidos con un único árido, podría ser utilizada como punto de partida para dosificaciones en función del los requerimientos de resistencia o de tasa de infiltración. Por ejemplo, al definir una resistencia minima de $2.5 \mathrm{MPa}$ a 28 d, de la Figura 6 (a) se puede observar que se obtendrán $15 \%$ de vacíos en el hormigón en estado endurecido, lo que estará asociado a una tasa de infiltración de $3 \mathrm{~mm} / \mathrm{s}$.

\subsection{The effect of the voids content over flexural strength and permeation}

Figure 6 (a) shows a relation between flexural strength at 28 days and the actual content of voids measured in all the specimens. Figure 6 (b) shows a relation between the permeation rates measured at 28 days and the actual void content.

Even when Figure 6 shows the results obtained with only one type of aggregate, this could be used as the starting point for doses based on permeation rates or strength requirements. For example, a minimum flexural strength of 2.5 MPa at 28 days Figure 6 (a) can be achieved with $15 \%$ of void content in hardened concrete which is associated to an infiltration rate of $3 \mathrm{~mm} / \mathrm{s}$.

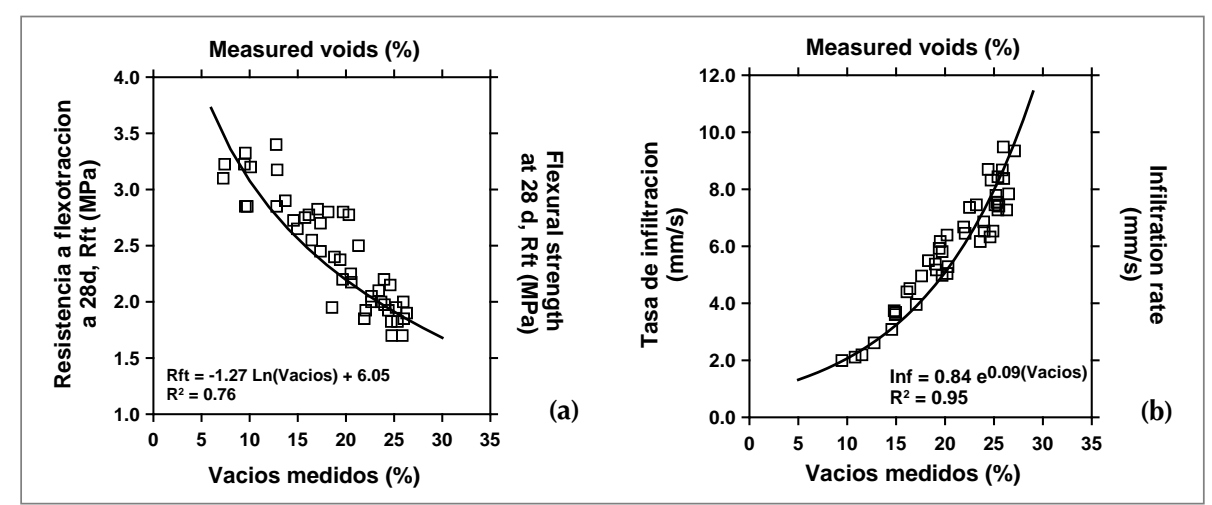

Figura 6. Relación entre porcentaje real de huecos y: a) la resistencia a flexotracción a 28 días y, b) la tasa de infiltración Figure 6. Relation between actual void content and: (a) The 28 days flexural strength and b) Permeation rate 


\subsection{Determinación del porcentaje de vacíos en el hormigón endurecido}

En la Figura 7 (a) y (b) se muestran resultados de dos métodos utilizados para determinar el porcentaje de vacíos para hormigones porosos: permeámetro de carga variable, y densidad en estado fresco de mezclas compactadas con rodillos. Ambos métodos ofrecen una buena correlación con el porcentaje de vacíos medidos en laboratorio. La densidad en estado fresco parece ofrecer mejores resultado, pero tiene el inconveniente que requiere de moldes especiales y un rodillo para compactar la mezcla. El permeámetro de carga variable puede ser utilizado para evaluar la mezcla puesta en terreno, y aparece como un buen método para control de calidad de las mezclas.

\subsection{Determining the void content in hardened concrete}

Figures $7(a)$ and (b) present the results of the two methods used to determine the void content in pervious concrete: a variable load permeameter and fresh unit weight of rolled compacted mixtures. Both methods offer a good correlation with the void content measured in the laboratory. The fresh unit weight seems to offer better results, but it has the inconvenient that requires special moulds and a roller to compact the mix. The "Falling Head Permeameter Test" seems to be a good method to control the quality of the mixture.

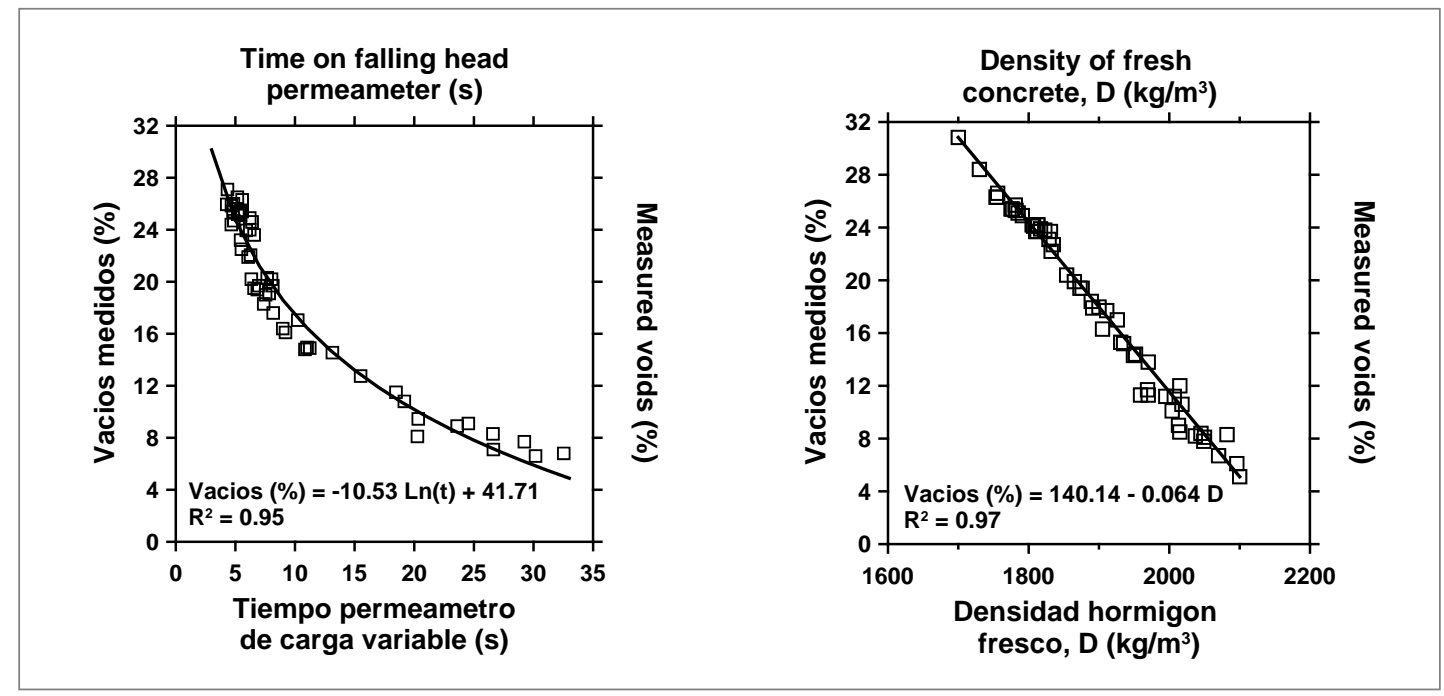

Figura 7. Correlación entre el porcentaje real de huecos y: a) el tiempo medido usando el permeámetro de carga variable y, b) la densidad en estado fresco del hormigón compactado con rodillo

Figure 7. Correlation between the real content of voids and: a) The time measured using the variable load permeameter b) Fresh unit weight of roller compacted fresh concrete.

\section{Conclusiones}

En este artículo se ha presentado la deducción de ecuaciones que permiten dosificar mezclas de hormigón permeable basado en el requerimiento de porcentaje interconectado de vacíos en la mezcla endurecida. Dieciocho diferentes mezclas fueron preparadas utilizando este sistema de dosificación, las que incluyeron razones agua-cemento desde 0.29 hasta 0.44 .

A partir de los resultados obtenidos, se recomienda utilizar razones $w / c$ entre 0.35 y 0.38 para mezclas de hormigón poroso. Mezclas con $w / c$ menores presentan muy baja resistencia y apreciable desprendimiento superficial de áridos. Mezclas con $w / c$ mayores presentan escurrimiento de la pasta de cemento y disminución notoria del porcentaje de vacíos.

\section{Conclusion}

This paper has shown the results of equations that will allow to dose pervious concrete mixtures based on the void interconnected content of the hardened mixture requirement. There were eighteen different mixtures prepared with this dosing method, which included water-cement rates from 0.29 to 0.44 .

Upon the results obtained, the recommendation for pervious concrete mixtures is to use $w / c$ ratios between 0.35 and 0.38 . Mixtures with smaller ratios show low strength and remarkable superficial aggregate loss. Mixtures with a higher w/c, show cement paste drainage and a notorious decrease of voids content. 
Para mezclas con razón $w / c$ constante, existe una cantidad óptima de cemento que maximiza la resistencia a flexotracción. Este comportamiento puede ser explicado por el importante efecto de la trabazón de los áridos y el reducido volumen de pasta de cemento sobre la resistencia a flexotracción de estas mezclas.

\section{Agradecimientos}

Agradecemos el importante apoyo del Proyecto FONDEF D00100I, "Sistemas estandarizados para soluciones de aguas lluvias" para el desarrollo de esta investigación.
Mixtures that have a constant $w / c$ show an optimum quantity of cement that maximizes flexural strength. The important effect of aggregate interlock and the reduced volume of cement paste over the flexural strength of these mixtures may explain this behavior.

\section{Acknowledgments}

The important support of FONDEF D00100I, project called "Sistemas estandarizados para soluciones de aguas Iluvias" (Standarized systems to rain water solution) is greatly acknowledged.

\section{Referencias / References}

ASTM International (2008), "Standard specification for Concrete Aggregates", ASTM C33.

Castro J. (2004), "Diseño de mezcla y construcción de pavimentos de hormigón poroso en Chile", Tesis de Magíster, Pontificia Universidad Católica de Chile, 188 pp.

Debo T. y Reese A. (1995), "Municipal Storm Water Management", Lewis Publishers. Londres, Inglaterra. EPA (1999), "Storm Water Technology Fact Sheet, Porous Pavement", EPA 832-F-99-023, Washington DC, USA. FCPA (1990), "Portland Cement Pervious Pavement Manual", Florida Concrete and Products Association Inc., Florida, USA. Fernández Luco L., Vitola L., Salminci P. (2002), "Estado del arte en el uso de hormigones porosos", XII Congreso Argentino de Vialidad y Tránsito, Buenos Aires, Argentina, Tomo II, pp761. (Trabajo publicado posteriormente por la Revista Carreteras, Año XLVI, Número $160)$.

GCPA (1997), "Recommended Specifications for Portland Cement Pervious Pavement", Georgia Concrete and Products Association, Inc, 1997 (www.pervious.info).

Ghafoori N. y Dutta S. (1995), "Pavement thickness design for no-fines concrete parking lots", Journal of Transportation Engineering, Vol 121, No6, pp. 476-484.

Kwiatkowski M. y Welker A. (2003), "Development of a Monitoring Program for a Porous Concrete BMP", World Water and Environmental Resources Congress, Philadelphia, Pennsylvania.

Meininger R. (1988), "No-Fines Pervious Concrete for Paving", Concrete International, Vol 10, No8, pp. $20-27$. Reyes F. y Torres A. (2002), "Effect of plastic fibers on flexion of drainable pavement structures", Revista Ingeniería de Construcción, Vol $17, N^{\circ} 2$, Mayo-Agosto, pp 93-102.

Smith D. (2001), Permeable Interlocking Concrete Pavements, Selection, Design, Construction, Maintenance, Second Edition. Interlocking Concrete Pavement Institute (ICPI). Washington, DC, Estados Unidos.

Solminihac H., Videla C., Fernandez B. y Castro J. (2007), "Desarrollo de mezclas de hormigón poroso para pavimentos urbanos permeables", Materiales de Construcción, Vol 57, 287, pp. 23-36. 